\title{
Gustavo Bueno (1924-2016)
}

BIBLID 0495-4548(2016)31:3p.413-414

DOI: $10.1387 /$ theoria. 17129

Con la muerte de Gustavo Bueno desaparece el último de los miembros del Consejo asesor de Theoría vinculado a la primera época de la revista (1952-1955). Bueno había sido becario del Instituto de Filosofía del CSIC en el que surge el proyecto de THEORía, primero como suplemento de Alcázar y luego como publicación independiente, bajo la dirección de Miguel Sánchez-Mazas ${ }^{1}$. Los integrantes de aquel núcleo fundador de THEORÍA recibieron a través de distintas vías los ecos de los debates filosóficos sobre la ciencia del primer tercio de siglo, y protagonizaron la primera recepción española del neopositivismo lógico. Como catedrático de Instituto en Salamanca y después en la Universidad de Oviedo, Bueno desarrolló a partir de aquí su propia concepción materialista de la ciencia, la teoría del cierre categorial, en un proyecto que se prolongaría seis décadas.

Del Círculo de Viena Bueno tomó principalmente el análisis formal, desgajándolo, eso sí, de la visión más amplia de la ciencia que los exiliados alemanes y austríacos promoverían luego en el mundo anglosajón. Frente a esta tradición hoy dominante, Bueno encuentra su propia fuente de inspiración en la Salamanca de los 1950, donde se dedica al estudio de la escolástica tardía española. De aquí toma Bueno la ontología trimembre que defendería años más tarde en los Ensayos materialistas (1972), así como su denominada lógica material: su teoría de los todos y las partes, así como sobre la identidad. Como Pierre Bourdieu, Bueno sólo admitirá su deuda con la escolástica medio siglo después, para sorpresa de muchos de sus discípulos, a quienes Bueno presenta su filosofía de la ciencia en discusión con el marxismo (Althusser, Sacristán). Era este el Oviedo de los años 1970, y en él asienta Bueno el tercer pilar de su teoría de la ciencia, apoyándose en la epistemología genética piagetiana: las operaciones del sujeto cognoscente se apoyan en manipulaciones materiales que siguen una estructura formal (algebraica, en los niños estudiados por Piaget). Con estos mimbres analíticos, escolásticos y estructuralistas, Bueno articuló una teoría de la ciencia que sólo podía ser singular.

Del análisis lógico se sirvió Bueno con propósitos principalmente clasificatorios, para sistematizar el conjunto de alternativas conceptuales con las que pretendía polemizar. Su visión central de la ciencia se articula, en cambio, sobre la intuición de que las operaciones del científico al manipular los objetos de su campo de estudio se rigen según un patrón formal que imponen los propios objetos. Bueno desarrolla esta intuición piagetiana con un armazón escolástico: los campos científicos constituirían totalidades ontológicas, separadas unas de otras (categorías cerradas). El científico aislaría verdades dentro de tales categorías como identidades operatorias: cuando una secuencia de operaciones con los objetos del campo estudiado conduce al científico una y otra vez a unos mismos resultados se verificaría en estos una forma de identidad (sintética). Las distintas ciencias se clasificarían así por el modo en que tales identidades se forman, con un mayor o menor grado de segregación de las opera-

1 E. Ronzón. "La revista Theoría y los orígenes de la filosofía de la ciencia en España." THEORLA 7, 1/2/3 (1992): 591-622. 
ciones subjetivas del científico de los resultados que alcanza (mayor en las ciencias naturales, menor en las ciencias sociales).

Bueno reivindicó le necesidad de filosofar sistemáticamente, frente a la filosofía rapsódica de la mayor parte de sus coetáneos. Sin embargo, de la teoría del cierre categorial, el núcleo de su sistema, nos lega principalmente un programa: los cinco volúmenes publicados (de un proyecto de quince, iniciado a mediados de los 1990) contienen principalmente la crítica de las teorías alternativas (la filosofía y la sociología de la ciencia contemporánea) y un esbozo de la teoría de los todos y las partes. Como el propio Bueno declaró ${ }^{2}$, la teoría de la ciencia dejó de interesar a su público y comenzó a dedicarse en las dos últimas décadas a formas más mundanas de ensayo. Queda como tarea para la Historia de la filosofía española dilucidar si este desinterés es pasajero u obedece a razones más profundas. Si la obra de Bueno puede ser todavía desarrollada en diálogo con otras corrientes hoy en auge, o si la teoría del cierre categorial, con toda su originalidad, fue simplemente el producto de la peculiar circunstancia biográfica de su autor. Si, como él mismo solía decir, pensar es pensar contra alguien, queda por ver si alguien piensa alguna vez contra Bueno.

La singularidad de Bueno se aprecia también en el modo en que desarrolló institucionalmente su filosofía, siguiendo el canon alemán: creó su escuela a través de un departamento universitario, fundó su propia revista y su propia editorial, sus propias series de congresos, e incluso su propia Fundación al dejar la Universidad de Oviedo. A pesar de la magnitud de sus logros, Bueno se quejó siempre la nula atención que recibía por parte de sus colegas españoles, cuando la obra e impacto institucional de todos ellos fue, casi siempre, comparativamente menor. Queda también para historiadores y sociólogos explicar esta falta de atención, pero podemos preguntarnos ya si una obra intelectualmente tan singular e institucionalmente tan local podía esperar mayor fortuna en la filosofía de la ciencia contemporánea. Al fin y al cabo, durante los últimos treinta años, los estudios metacientíficos (filosofía, historia y sociología) se han globalizado, creándose comunidades internacionales de especialistas, organizadas conforme al modelo anglosajón, en las que los debates (en inglés) sobre la ciencia alcanzan una complejidad y detalle que empequeñece cualquier análisis de la escuela ovetense.

Durante sus últimos años, Bueno denostó una y otra vez semejante globalización por razones principalmente políticas: la lengua sería compañera del imperio, y su punto de vista sobre la ciencia (y cualquier otro ámbito de la filosofía) constituiría así la expresión de una tradición española, inconmensurable con el filosofar anglosajón. Sin embargo, la propia revista Theoría ha seguido paulatinamente ese curso globalizado, del mismo modo que se escribe en inglés la mayor parte de la filosofía de la ciencia que se hace hoy en España. El espacio intelectual en el que se articula el debate que Bueno contribuyó a fundar entre nosotros está ya lejos de las instituciones buenistas. Pero sin el impulso de Bueno y la generación que con él desaparece este espacio habría sido muy distinto. Por eso, es justo rendirle hoy homenaje.

DAVID TEIRA UNED

dteira@fsof.uned.es

2 L. Paez. "Gustavo Bueno: No tengo tiempo para estar enfermo". El Mundo 1/9/2014. Disponible en: http://www.elmundo.es/cultura/2014/09/01/5403970eca4741d6698b4585.html (Visitado el 12 de agosto de 2016) 